\title{
前後の危険に対する自動車用触覚警報システムに関する基礎的 研究*
}

\author{
村田厚生 $*$, 家守 進**，森若 誠**
}

\begin{abstract}
The aim of this study was to improve driving safety using a vibrotactile warning system. The effectiveness of vibrotactile warning system was compared between the system that made use of apparent movement using 2point stimuli and the system of single point stimulation. The participants were required to simultaneously carry out a tracking task, a switch pressing task, and a judgment task of information which randomly appeared on the front or the rear. The tracking error, the correct percentage of switch pressing, and the reaction time and the percentage correct reaction to the front or rear stimulus were measured. It was examined how age, the method of warning presentation (no warning, vibrotactile stimulation by apparent movement, and single-point vibrotactile stimulation), and the attachment location of tactors (arm, leg, and stomach/back) affected the measures above. It was confirmed that the tactile warning were effective for both young and older adults. The vibrotactile stimulation on leg led to higher hit rate, in particular, for older adults irrespective of the method of warning presentation. The warning presentation by vibrotactile apparent movement led to the slower reaction to the rear danger than the single-point vibrotactile stimulation.
\end{abstract}

触覚警報によって危険場面に対する反応時間の短縮を図り，安全性を向上させることを目的とし，仮現運 動による警報提示, 単一の振動刺激による警報提示, 警報なしの3 条件を比較し, 最適な触覚警報提示方法 を明らかにした. 被験者には, トラッキング作業, スイッチ操作, 前後方向の危険場面に対する判断作業の 三重課題を行わせ，トラッキング誤差，スイッチ操作の正答率，前後方向の危険場面に対する反応時間・正 答率を計測した．若年者, 高齢者ともに触覚刺激提示のある方が有効であり, 高齢者は特に脚への提示によ って後方の危険場面に対する反応時間, 正答率が向上した。 また, 触覚警報の提示方法に関しては, 仮現運 動を利用した提示よりも単一の振動刺激のほうが反応時間が速くなった。

(キーワード：自動車用警報システム，触覚警報，反応時間，仮現運動，高齢者）

\section{1.はじめに}

車の運転では, 情報の知覚・認知でミスが生じた場合, 事故へとつながる危険性がある。自動車運転中の情報の 90\%以上が視覚であり ${ }^{1)}$, カーナビゲーションシステムや 携帯電話などの車載情報機器の普及により, ドライバの 知覚・認知の負担が増加傾向にある2).このような状沉を 受けて, 自動車の安全運転支援システムの研究が行われて いるが，支援情報を視覚によって提示するものが多く3,4), 運転支援システムによる視覚情報の知覚・認知への過大 な負担が事故の危険性を高める。したがって, 視覚情報 の知覚・認知への負担を増加させることなく安全運転を

\footnotetext{
*受付：2011年2月7日＼cjkstart受理：2011年8月1日

$* *$ 岡山大学大学院自然科学研究科

Graduate School of Natural Science and Technology, Okayama University
}

支援するには，視覚以外の感覚への警報提示が有効であ ると考えられる。

運転環境においては，ほとんどの情報は視覚，聴覚に よって提示されるため，危険状況の警報が視覚または聴 覚によって提示された場合には，危険情報と警報が同種 の感覚情報として与えられ，同種の感覚情報同士の干涉 現象が生じる可能性がある。触覚警報では，このような 干渉がなく，有効性を発揮することが期待される．また， 感覚の通信容量に関しては，視覚 $10^{7} \mathrm{bit} / \mathrm{s}$, 聴覚 $10^{5} \mathrm{bit} / \mathrm{s}$, 触覚 $10^{6} \mathrm{bit} / \mathrm{s}$ であることが $\mathrm{Schmidt}^{5)}$ によって指摘されて いる．視覚の次に触覚の通信容量が多いため，触覚に警 報提示を行えば，短時間に多くの正確な情報を伝達でき ると考えられる。

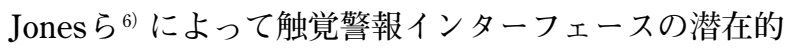
な有用性は指摘されているが，いかに触覚警報を実現し ていくべきか（例えば，どの身体部位にどのように提示 するか）に関しては，設計で利用可能なデータが不足し 
ている.

Hoら7 10)によって, 車外の危険場面をドライバに知ら せる場合, 触覚と聴覚の警報信号の使用は効果的である ことが示されている。また，田中ら ${ }^{11)}$, Murataら ${ }^{12)}$ ，山 田 ${ }^{13)}$ は, 警報システムとしての触覚警報の有用性を指摘 した. Mohebbiら ${ }^{14)} も$, 携帯電話（ハンズフリ一使用） での会話中の追突警報として, 触覚への警報提示がある 場合にブレーキ操作の反応時間が最も短くなることを示 した，これらの方法は，すべて単一の振動刺激の警報に よって危険場面を知らせるものである。

触覚に関しては，方向性のある警報提示を行った場合 の反応時間が最も短く, 効果的に警報提示を行うには方 向性のある提示が重要な役割を果たすことがHoら Murataら ${ }^{12)}$ によって示されているため，振動刺激によっ て方向性のある警報提示を行うことが有効であると考え られる. Murataらの研究 ${ }^{22)}$ では，ステアリングのグリッ プ部分（左右）に振動子を取り付け, 危険が存在する方 向側の振動子を振動させて方向性を付与することによっ て, 危険場面への反応時間が短くなった. Hoらの研究 では, 前後の危険に対して腹部もしくは背部への振動刺 激によって方向性を付与した警報を与えることで，危険 場面への反応時間が短くなることを示した．左右方向に 関しては, 例えば左手一右手, 左脚一右脚, 左脇腹一右 脇腹のように, 前後方向に比べると方向性を付与しやす い.したがって本研究では, 方向性を付与しにくい前後 方向に注目した。

単一刺激を左右または前後に与える方向性付与の方法 とは別に, 時間差をもって振動刺激を与える仮現運動 (大山ら ${ }^{15)}$ によれば, 仮現運動とは対象の客観的な運動が 存在しないにもかかわらず，運動が知覚される場合の見 えの運動のことである）を生起させることでも警報提示

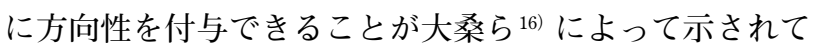
いる. 大桑らの研究16) では, 20歳～40歳代の被験者に対 して, 大腿部に仮現運動による振動提示を行い, これを 被験者が知覚可能かどうかを検討した。刺激提示時間, 刺激時間間隔, 刺激間時間間隔, 刺激距離, 振動の周波 数, 強度の組み合わせから仮現運動が知覚されるための 条件を求め, 振動素子を配置した振動シートを試作し, ドライビングシミュレータを用いた運転支援状況で検証 を行った結果, 運転作業中でもシートを介した振動刺激 による仮現運動を知覚可能であることを示した。仮現運 動は運転支援情報として危険対象の方向を直感的にドラ イバへ伝える有効な方法であり, 方向をより強く意識し て知覚でき, 単一刺激よりも危険場面に対する速い反応

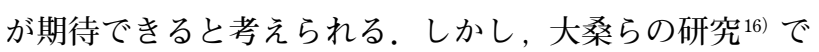

は，仮現運動による危険場面への警報の有効性は検証さ れていない。

触覚警報に関するこれまでの研究8 14,16) では, 触覚刺 激部位が手, 脚, 腹部一背部のいずれか一箇所に限定さ れており，振動刺激部位の効果の違いは検討されていな い。また, 高齢者は, 若年者よりも知覚・認知 (判断) · 運動能力が低下しているため，警報システムによって， 低下したこれらの機能が補われ，危険場面の見落としに よる事故防止につながると考えられる。しかし，上記の 研究8 14,16) では, ほとんどが若年者を対象としており, 高 齢者に対する触覚警報の有効性については検討されてい ない.

そこで本研究では，単一刺激による触覚警報と比較し ながら, 仮現運動を用いた触覚警報の有効性を, より実 践的な模擬運転環境下で検証した。さらに，触覚警報を 身体のどの部位（大腿部（大腿二頭筋）に腕（下腕部）, 背中十腹（胸椎第7椎十第6肋間）の3箇所）に提示する のが効果的か, 高齢者においても仮現運動の有効性が見 られるかについても調查した，以上のように，触覚警報 提示方法（単一刺激，仮現運動)，身体部位，年齢を実験 要因として，これらの要因がトラッキング作業における 車両中心と走行車線中心とのずれ，スイッチ押し作業の 反応時間・正答率，前後方向の危険場面への反応時間 · 反応の正答率へ及ぼす影響を明らかにし，前後の危険に 対する自動車用警報システム開発のための基礎を得るこ とを目的とした。

\section{2. 実験方法}

\section{2-1. 被験者}

若年者 10 名 (21歳 24 歳, 平均 $22.61 \pm 1.56$ 歳), 高齢 者10名（65歳～76歳，平均 68.35 土3.48歳）の計 20 名を 被験者とした。全員普通自動車免許を有し, 視覚系及び 精神・神経系に異常がない者とした。被験者には, 実験 の目的・内容を十分に説明し, 実験参加へのインフォー ムドコンセントを得た.

\section{2-2. 実験機器}

触覚への振動刺激提示には, 振動タクタ (Audiological Engineering Corporation製Tactaid VBW32 transducer）を 使用し, 振動周波数, 強度の調節はファンクションジェ ネレータ（GWInstek社製SFG-2004）で行った。トラッキ ング作業，スイッチ操作では, 村田ら ${ }^{17)}$ と同じ実験機器 を用いた。トラッキング作業では，デスクトップパソコ 
ン (mouse computer, 0602Lm-i211B)，プロジェクタ (EPSON, EMP-S4), ハンドル (Logitech, MOMO, 直 径は $24 \mathrm{~cm}$ ）を用いた。 スイッチ操作では，ノート型パソ コン (HP, NX6120)，デジタルI/Oカード (Interface, PIO-24W (PM)), 画面を被験者の正面に表示するための 液晶ディスプレイ（SONY, SDM-N50）を用いた。

\section{2-3. 作業内容}

作業内容は, 主作業をシミュレータを用いたトラッキ ング作業, 副次作業を課題に対するスイッチ押し作業, 前後方向に現れる危険場面に対する判断作業とした.

\section{2-3-1. トラッキング作業}

トラッキング作業の詳細は, 村田ら ${ }^{17)}$ に詳述されてい る. Hot Soup Processor3.2を用いて3次元運転シミュレー ションプログラムを作り, トラッキング作業を被験者に 課した.シミュレーションプログラムは約 $50 \mathrm{~Hz}$ で実行 し, 画面の解像度は $1024 \times 768$ ピクセル, 画面のリフレ

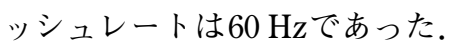

画面内には1車線道路, 路側帯, ガードレール, 木を設 けた。矢印を操作対象, 道路の真ん中に描かれた中心線 を追従対象とした（図1（a）参照）。トラッキング作業用 シミュレーションプログラムでは, 道路の幅を $3.25 \mathrm{~m}$ と した時に仮想車の前進速度が約 $35 \mathrm{~km} / \mathrm{h}$ になるように設 定した。また，ハンドル操舵角 $\alpha$ とシミュレーションプ ログラムの仮想車のヨー角速度 $\omega$ との関係を $\omega=0.078 \alpha$ と した。走行道路は正弦波（周期20秒）状に緩やかに左右 交互にカーブする形状とし, 提示画面中に他の車は存在 しない走行条件とした。 トラッキング作業では, 矢印の 頂点を道路の中心線（ターゲットライン）にできるだけ 正確に合わせるように被験者にステアリングを操作させ た。実験中， 0.1 秒ごとにターゲットとなる道路の中心線 と操作対象となる矢印の頂点との相対距離 (mm単位) を記録し，この平均をトラッキング誤差とした。また， スクリーン上の $1 \mathrm{~cm}$ は実車であれば約 $3.25 \mathrm{~cm}$ となる.

\section{2-3-2. スイッチ操作}

ハンドルに取り付けられたスイッチを押すことにより， ハンドル前方に設置されたディスプレイに表示される課 題に回答する作業を被験者に課した。課題は 10 秒につき 1 課題出題され，10秒以内に回答するように指示した. 被 験者には, 速く回答することは要求せず, 10 秒以内であ れば押し直しを認めた。10分間で計60課題を被験者に遂 行させた。課題はライト, ワイパー, ハザード, オート ロックのいずれかを選択するものであり，ライト，ワイ パー, ハザード, オートロックの 4 種類をランダムに表示 した。課題画面を罒2に示す。

\section{2-3-3. 危険場面に対する判断作業}

本実験では, 自動車運転中に存在する前方, 後方の危 険場面に対する判断作業を被験者に課した。実際の運転 において起こり得るものを想定し, 前方は危険を促す標 識に対する判断, 後方は後続車の行動に対する判断を行 わせた。前方における危険場面として, 対向車が中央線 を大きくはみ出してくる, 自動車等が飛び出してくると いうことも考えられる。しかし，本実験で用いたトラッ キングコースには大きなカーブが存在しないため, 対向 車が中央線を大きくはみ出してくるということは, 現実 的にほとんど起こらない. また, 自動車等の飛び出しに ついても，前方よりも側方に対する危険場面であるため， 作業として妥当でない. 標識によって運転者に前方の危 険への注意を促し, 自動車の速度を落とす等の対処を行 うことは, 実際の自動車の運転において十分起こり得る ため, 前方における危険判断作業として妥当であると考 えた。

前方の危険場面に対する判断作業では，トラッキング 作業画面内に表示される 6 種類の標識のうち, 「すべりや すい」（図1（b）のA）,「動物が飛び出すおそれあり」 (図1（b）のB), 「落石のおそれあり」(図1（b）のC）が 表示された場合にブレーキ側のフットスイッチを踏んで 反応するように指示した. 図1（b）のD-Fに対しては反 応する必要がないことを指示した，標識A-Fは1回の実験 (2-4で述べるように10分間) でランダムに 20 回表示され， 危険場面に相当する A, B，Cを各2回ずつ計6回提示した.

後方の危険場面に対する判断作業では, 後方スクリーン からバックミラーを介して映し出される後続車との車間 距離変化（後続車が一定の車間距離を保って追従している 画面, 接近して来た画面, 後退して行った画面の3パター ン）のうち，接近して来た場合にアクセル側のフットス イッチを踏んで反応するように指示した．罒3に後方危険 場面とその他の場面（後退して行った画面）を示す。後 続車は 1 回の実験（10分間）でランダムに 20 回接近また は後退を行い, そのうち接近してくる場合は6回とした。

前後あわせて，1回の実験で危険場面を12回（前と後 で6回ずつ）発生させた.スイッチ操作は 10 秒に 1 回の間 隔, 危険判断作業はランダムな時間間隔で被験者に提示 したため，2つの作業が同時に出現する場合がある（オー バーラップの比率は, 平均で約 $83 \%$ あっむた). 被験者に は，危険判断作業を最優先するように指示した。

\section{2-4. 実験条件・要因}

年歯令, 刺激提示法, 刺激提示部位の 3 つを実験要因と した。年齢は被験者間要因, その他の要因は被験者内要 
(a)

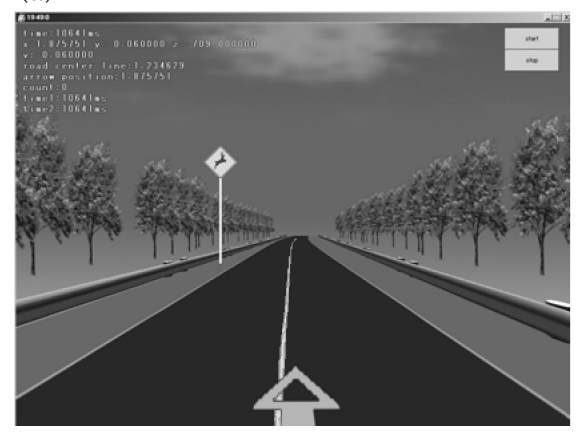

(b)

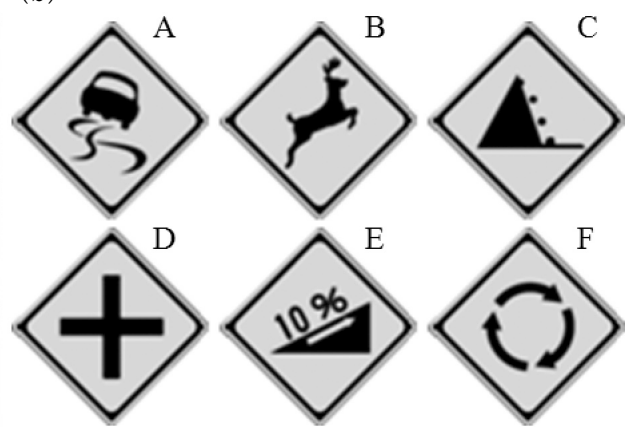

図 1 （a）前方の画面に提示される危険情報と（b）実験で用いた道路標識

Fig. 1 (a) Dangerous information displayed on front screen and (b) traffic signs used in the experiment.

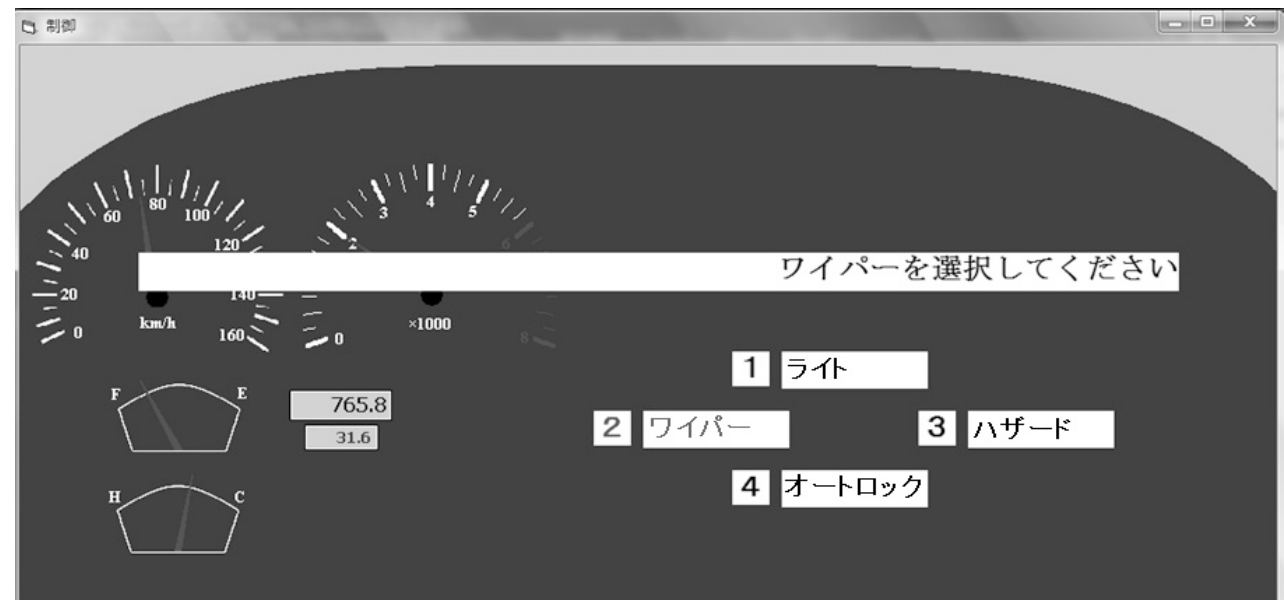

図2 実験で用いたスイッチ押し作業画面

Fig. 2 Display of switch pressing task.

(a)

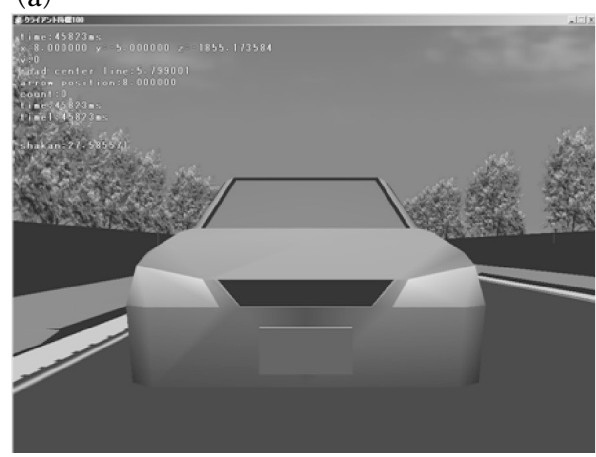

(b)

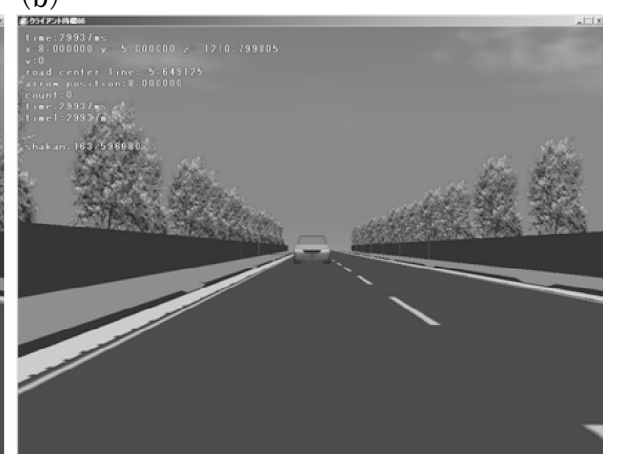

図3（a）後方の画面に提示される危険状態と（b）危険でない状態

Fig. 3 Dangerous situation and (b) the situation not regarded as dangerous displayed on rear screen (back mirror).

因である，実験条件は, 刺激提示法の 2 種類（仮現運動に よる警報提示，単一の振動による警報提示)，刺激提示部 位の 3 種類（腕, 脚, 背中 $/$ 腹部) の組み合わせによる 6 条件と，警報なしの1条件を加えた計 7 条件とした。1条
件での作業時間を 10 分とした。

刺激提示方法, 刺激提示部位の詳細を以下に示す.

(1) 刺激提示方法

仮現運動による警報提示，単一の振動刺激による警報 
表 1 仮現運動による振動条件

Tab. 1 Condition for vibrotactile stimulation by apparent movement.

\begin{tabular}{|l|c|c|c|c|c|c|}
\hline & $d[\mathrm{~ms}]$ & SOA [ms] & ISI [ms] & $E[\mathrm{~V}]$ & $f[\mathrm{~Hz}]$ & $D[\mathrm{~mm}]$ \\
\hline Arm & 125 & 175 & 50 & 10 & 281 & 65 \\
\hline Leg & 75 & 150 & 75 & 10 & 251 & 48 \\
\hline $\begin{array}{l}\text { Stomach } \\
\text { and back }\end{array}$ & 150 & 150 & 0 & 10 & 249 & \\
\hline
\end{tabular}

表2 単一振動刺激による振動条件

Tab. 2 Condition for single-point vibrotactile stimulation.

\begin{tabular}{|l|c|c|c|}
\hline & $d[\mathrm{~ms}]$ & $E[\mathrm{~V}]$ & $f[\mathrm{~Hz}]$ \\
\hline Arm & 300 & 10 & 281 \\
\hline Leg & 225 & 10 & 251 \\
\hline $\begin{array}{l}\text { Stomach } \\
\text { and back }\end{array}$ & 300 & 10 & 249 \\
\hline
\end{tabular}

提示，警報を与えない場合の3水準で実験を実施した。

(2) 刺激提示部位

（A）右腕の下腕部と（B）右脚の大腿部には振動子を $2 つ ，(C)$ 背中 (胸椎第7椎) および腹部 (第6肋間) に はそれぞれ1つずつ振動子を設置し，計 3 水準で実験を実 施した。

家守らの研究 ${ }^{18)}$ に従って, 各部位に適した周波数と強 度で警報提示を行った．標識が画面に出現した時点（前 方), 後続車が接近または後退動作を開始した時点（後 方）で警報を提示した。また，振動刺激によって仮現運 動を生起させるには，刺激提示時間 $(d)$, 刺激時間間隔 (SOA：Stimulus Onset Asynchrony)，刺激間時間間隔 (ISI : Interstimulus Interval), 刺激距離 $(D)$, 周波数 $(f)$, 強度 $(E)$ を適切な值で組み合わせる必要がある. そこで, 本実験の前に, 各值の組み合わせを変更し, 仮 現運動が生起する条件を求めた。この結果から, 仮現運 動による警報提示，単一の振動刺激による警報提示に関 しては表 1 と表 2 に示す値を用いた。刺激提示時間 $(d)$, 刺激時間間隔，刺激間時間間隔の関係を図4に示す.

\section{2-5. 実験手順}

全ての被験者で, 前 $\rightarrow$ 後ろ, 後ろ $\rightarrow$ 前の仮現方向を感 知できることを確認した上で，実験を行った。自動車用 シートに被験者を座らせ, 運転作業を行いやすいように シートの位置を調節させた。同時に，後方のスクリーン が見えるようにバックミラーを調節させた。その後，各 部位に振動子を取り付け，作業を開始した。

実験開始前には，実験内容，作業内容を十分に説明し，

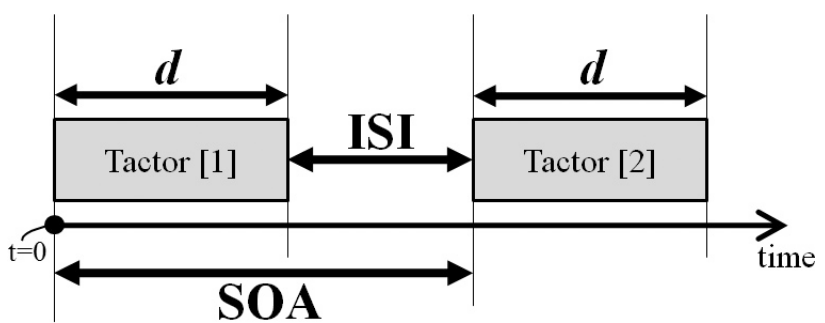

図4 刺激提示時間 $(d)$, 刺激時間間隔 $(\mathrm{SOA})$, 刺激間時間 間隔（ISI）の説明

Fig. 4 Explanation of stimulus duration $(d)$, stimulus onset asynchrony (SOA) and interstimulus interval (ISI).

各作業に関して実際に練習を行わせ，実験者が被験者の 作業内容の理解度が十分であると判断した時点で，実験 を開始した。実験開始と同時に，トラッキング作業，課 題に対するスイッチ操作，危険場面に対する判断作業を 行わせた．2-4で述べた7条件の実施順序は，被験者ごと にランダムにした。実験間では，2分程度の休悡を設けた。

トラッキング作業に関しては，中心線からのずれ（図 1 （a）参照）ができる限り小さくなるように作業を実施 させた。スイッチ操作では，できる限り正確に作業を遂 行するように教示した．前後方向の危険に対する判断作 業では，できる限り速く正確に作業を遂行するように教 示した。本研究で課したスイッチ操作に関しては，実車 においても前後方向の危険に対する判断のように緊急性 を要求されるものではないため，できる限り正確に作業 を遂行するように指示し，迅速性の条件を作業教示に含 めなかった。したがって，本研究ではスイッチ操作の作 業時間を評価しなかった。

\section{2-6. 評価指標}

刺激提示方法，刺激提示部位の影響を評価するため， 以下の評価指標を用いた。

(1) トラッキング誤差

操作部の矢印の中心と, ターゲットの走行車線の中心 線のズレを平均して視野角に変換した值.

(2) スイッチ操作の正答率

スイッチ操作における表示された課題に対する回答の 正答率 $($ 正答数 $/$ 回答数 $(1$ 条件で 60 回 $))$

（3）危険場面に対する反応時間

前方および後方画面に危険場面が表示されてからフッ トスイッチを踏むまでの時間.

\section{（4）危険場面に対する反応の正答率}

前方拉よび後方に表示された危険場面に対して，反応 すべき場面で正しく反応した割合. 


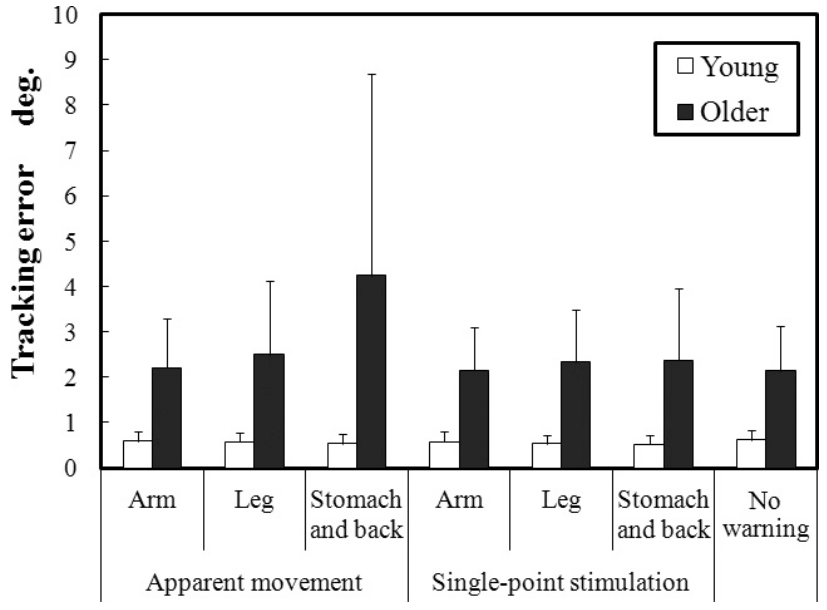

図5 年齢, 刺激提示方法, 刺激提示部位によるトラッキン グ䛊差の比較

Fig. 5 Tracking error as a function of age, type of warning and attachment location of tactors.

\section{3. 実験結果}

\section{3-1. トラッキング誤差}

四5に年齢，刺激提示方法（仮現運動と単一の振動刺 激, 刺激なし), 刺激提示部位（腕, 脚, 背中と腹部の 3 水準) でトラッキング䛊差を比較した結果を示す。トラ ッキング誤差に対して, 年齢, 刺激提示方法（仮現運動 と単一の振動刺激の 2 水準), 刺激提示部位 (腕, 脚, 背 中と腹部の 3 水準) を要因とする 3 元配置の分散分析を実 施した結果，年齢の主効果 $(\boldsymbol{F}(1,18)=17.929, \boldsymbol{p}<0.01)$ のみが有意であった。

トラッキング誤差に対して年歯, 刺激提示方法（仮現 運動の腕, 脚, 背中と腹部と単一の振動刺激の腕, 脚, 背中と腹部, 振動刺激なしの 7 水準) を要因とする 2 元配 置の分散分析を行ったところ, 年齢 $(\boldsymbol{F}(1,18)=19.760$, $\boldsymbol{p}<0.01)$, 年歯令と各部位での刺激提示法の交互作用 $(\boldsymbol{F}$ $(6,18)=2.284, \boldsymbol{p}<0.05)$ にそれぞれ有意差が確認され た. 若年者, 高齢者について, トラッキング誤差に対す る刺激提示方法間でFisherのPLSDによる多重比較を実施 した結果を表 3 に示す。以上のように，高齢者に関して は，仮現運動による提示を背中及び腹部に与えた場合の トラッキング䛊差が大きくなった.

\section{3-2. スイッチ操作の正答率}

図6に年齢, 刺激提示方法（仮現運動と単一の振動刺 激, 刺激なし), 刺激提示部位（腕, 脚, 背中と腹部の 3 水準) でスイッチ操作の正答率を比較した結果を示す.

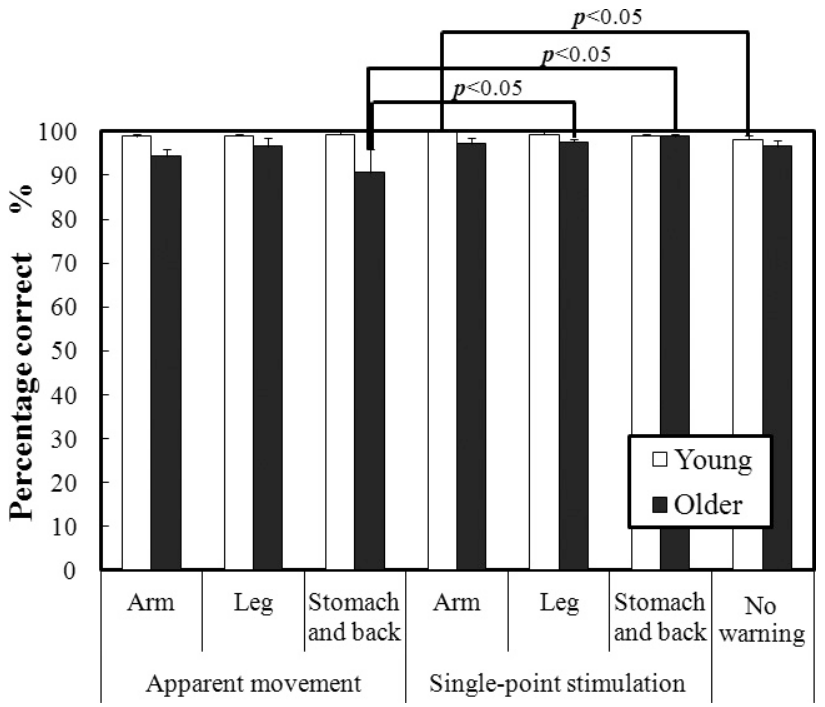

図6 年齢, 刺激提示方法, 刺激提示部位によるスイッチ操 作作業の正答率の比較

Fig. 6 Percentage correct in the switch operation task as a function of age, type of warning and attachment location of tactors.

スイッチ操作の正答率に対して, 年齢, 刺激提示方法 (仮現運動と単一の振動刺激の 2 水準)，刺激提示部位（腕， 脚, 背中と腹部の 3 水準) を要因とする 3 元配置の分散分 析を実施した結果，年歯令 $(\boldsymbol{F}(1,18)=10.619, \boldsymbol{p}<0.01)$ と刺激提示方法 $(\boldsymbol{F}(1,18)=5.088, \boldsymbol{p}<0.05)$ の主効果か 有意であった。

スイッチ操作の正答率に対して年齢, 刺激提示法（仮 現運動の腕, 脚, 背中と腹部と単一の振動刺激の腕, 脚, 背中と腹部, 振動刺激なしの7水準）を要因とする 2 元配 置の分散分析を行ったところ，年齢 $(\boldsymbol{F}(1,18)=10.758$ ， $\boldsymbol{p}<0.01 ）$ に有意差が確認された．若年者，高歯者につい てそれぞれ刺激提示法（2水準）と刺激提示部位を要因と する 2 元配置の分散分析を行ったところ，若年者は刺激提 示法 $(\boldsymbol{F}(1,9)=7.223, \boldsymbol{p}<0.05)$ に有意差が確認された. 高齢者に関しては，有意差は確認されなかった。若年者， 高齢者で，スイッチ操作の正答率に対する刺激提示方法 間でFisherのPLSDによる多重比較を実施した結果，罒6 に示すような有意差が確認された。

以上のように, 高齢者に関しては, 仮現運動による振 動刺激を背中及び腹部に与えた場合のスイッチ操作の正 答率が低くなった。

\section{3-3. 前方の危険場面に対する反応時間}

困7に年齢，刺激提示方法（仮現運動と単一の振動刺 激, 刺激なし), 刺激提示部位（腕, 脚, 背中と腹部の 3 水準）で前方の危険場面に対する反応時間を比較した結 
表3＼cjkstart年齢群ごとのトラッキング誤差に対するFisherのPLSDによる多重比較結果

Tab. 3 Results of multiple comparisons for tracking error by Fisher's PLSD for each age group.

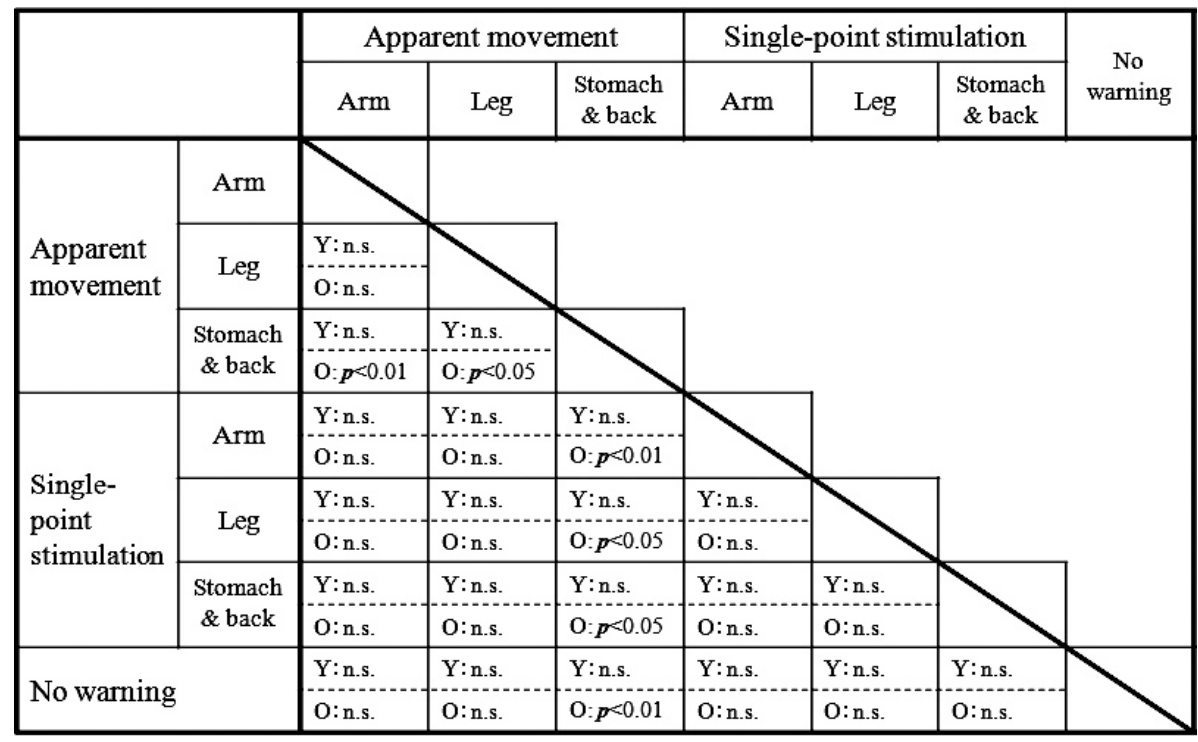

$\mathrm{Y}:$ Results on young adults

$\mathrm{O}:$ Results on older adults.

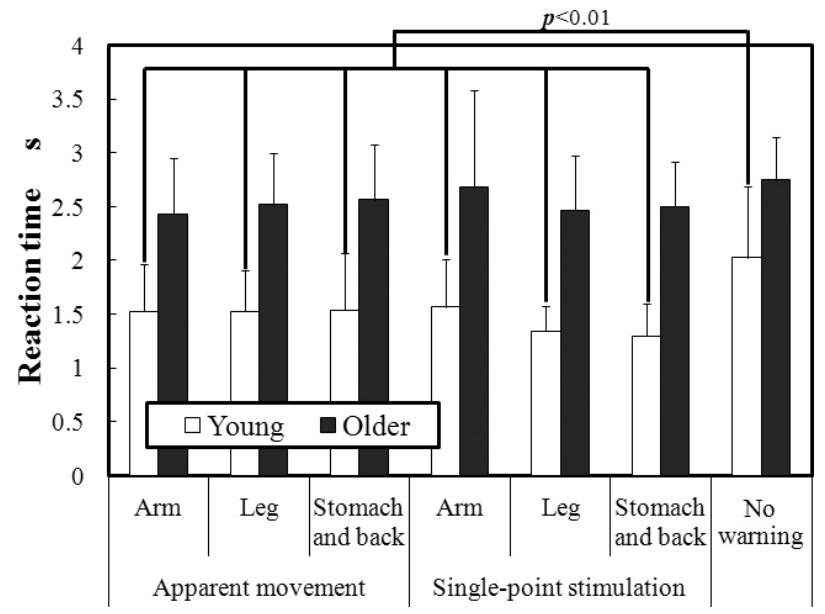

図7 年歯, 刺激提示方法, 刺激提示部位による危険判断作 業（前方）の反応時間の比較

Fig. 7 Reaction time to frontal dangerous information as a function of age, type of warning and attachment location of tactors.

果を示す．前方の危険場面に対する反応時間に対して， 年歯, 刺激提示法, 刺激提示部位を要因とする 3 元配置 の分散分析を行ったところ，年齢 $(\boldsymbol{F}(1,18)=50.036$ ， $\boldsymbol{p}<0.01 ）$ の主効果のみに有意差が確認された.

前方の危険場面に対する反応時間に対して, 年齢, 刺 激提示法 (仮現運動の腕, 脚, 背中と腹部と単一の振動 刺激の腕, 脚, 背中と腹部, 振動刺激なしの7水準) を要 因とする 2 元配置の分散分析を行ったところ, 年歯 $(\boldsymbol{F}$ $(1,18)=45.788, \boldsymbol{p}<0.01)$ ，刺激提示法 $(\boldsymbol{F}(6,18)=3.350$ ， $\boldsymbol{p}<0.01 ）$ の主効果に有意差が確認された．若年者，高歯 者で，前方の危険場面に対する反応時間に関して，刺激 提示方法間でFisherのPLSDによる多重比較を実施した結 果，図7に示すような有意差が確認された。

\section{3-4. 後方の危険場面に対する反応時間}

困8に年歯令，刺激提示方法（仮現運動と単一の振動刺 激，刺激なし），刺激提示部位（腕，脚，背中と腹部の3 水準）で後方の危険場面に対する反応時間を比較した結 果を示す。後方の危険場面に対する反応時間に対して， 年齢，刺激提示方法（仮現運動と単一の振動刺激の 2 水 準), 刺激提示部位（腕，脚，背中と腹部の 3 水準）を要 因とする 3 元配置の分散分析を実施した結果，年齢（F $(1,18)=14.902, \boldsymbol{p}<0.01)$ と刺激提示方法 $(\boldsymbol{F}(1,18)=$ $13.814, \boldsymbol{p}<0.05)$ の主効果が有意であった。

後方の危険場面に対する反応時間に対して，年齢，刺 激提示法（仮現運動の腕，脚，背中と腹部と単一の振動 刺激の腕，脚，背中と腹部，振動刺激なしの7水準) を要 因とする 2 元配置の分散分析を行ったところ，年齢（F $(1,18)=14.563, \boldsymbol{p}<0.01)$ ，刺激提示法 $(\boldsymbol{F}(6,18)=$ $19.809, \boldsymbol{p}<0.01)$ の主効果に有意差が確認された．若年 者, 高齢者で，後方の危険場面に対する反応時間に関し て，刺激提示方法間でFisherのPLSDによる多重比較を実 施した結果を表4にまとめる.

高齢者に関しては，単一刺激，仮現運動のいずれに関 しても，脚に対する反応時間が短くなる傾向が認められ 


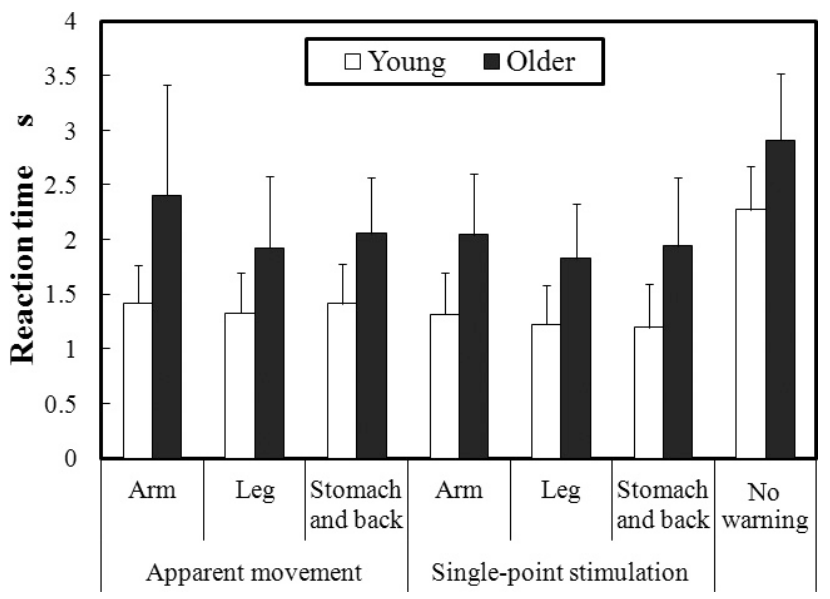

図8 年齢, 刺激提示方法, 刺激提示部位による危険判断作 業（後方）の反応時間の比較

Fig. 8 Reaction time to rear dangerous information as a function of age, type of warning and attachment location of tactors.

た (図8参照).

\section{3-5. 前方の危険場面に対する正答率}

図9に年齢, 刺激提示方法（仮現運動と単一の振動刺 激, 刺激なし), 刺激提示部位（腕, 脚, 背中と腹部の3 水準）で前方の危険場面に対する正答率を比較した結果 を示す。前方の危険場面の正答率に対して, 刺激提示方 法 (仮現運動と単一の振動刺激の 2 水準), 刺激提示部位 (腕, 脚, 背中と腹部の 3 水準) を要因とする 3 元配置の 分散分析を行ったところ, 年齢 $(\boldsymbol{F}(1,18)=10.150, \boldsymbol{p}<$ 0.01）に有意差が確認された。

前方の危険場面の正答率に対して, 年齢, 刺激提示法 （7水準）を要因とする2元配置の分散分析を行ったとこ ろ，年歯 $(\boldsymbol{F}(1,18)=11.695, \boldsymbol{p}<0.01)$ に有意差が確認 された。若年者, 高齢者で, 前方の危険場面に対する正 答率に関して, 刺激提示方法間でFisherのPLSDによる多 重比較を実施した結果，罒9に示すような有意差が認めら れた。

\section{3-6. 後方の危険場面に対する正答率}

図10に年齢，刺激提示方法（仮現運動と単一の振動刺 激, 刺激なし), 刺激提示部位（腕，脚，背中と腹部の3 水準) で後方の危険場面に対する正答率を比較した結果 を示す，後方の危険場面に対する正答率に対して，年歯令， 刺激提示方法（仮現運動と単一の振動刺激の 2 水準）, 刺 激提示部位（腕，脚，背中と腹部の 3 水準）を要因とする 3 元配置の分散分析を実施した結果，いずれの主効果も有 意ではなかったが，年齢と刺激提示部位の交互作用が有

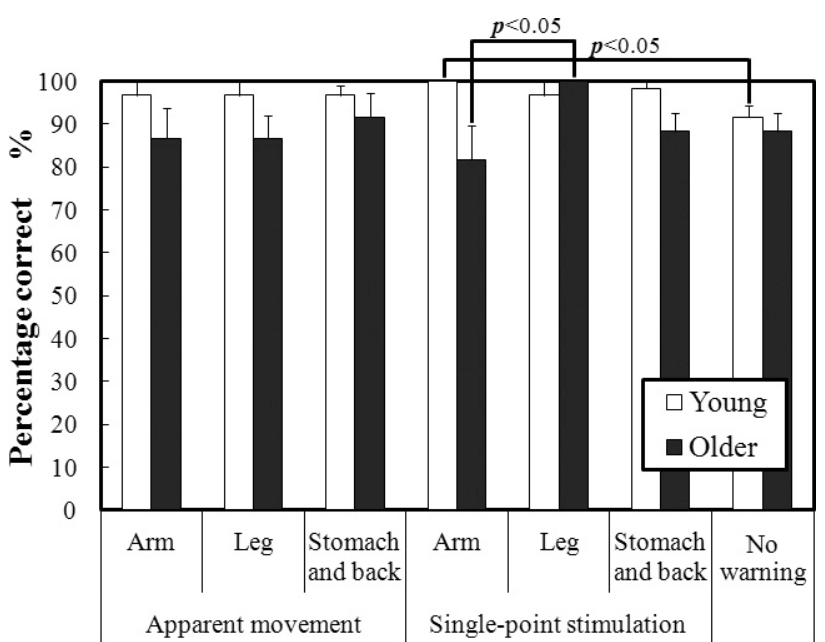

図9 年齢, 刺激提示方法, 刺激提示部位による危険判断作 業（前方）の正答率の比較

Fig. 9 Percentage correct in frontal danger judgment task as a function of age, type of warning and attachment location of tactors.

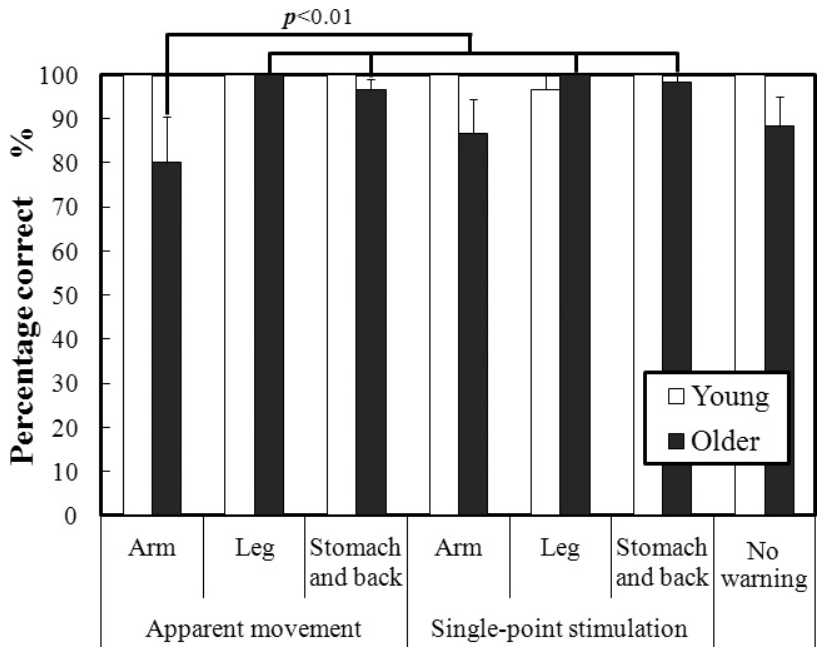

図 10 年齢, 刺激提示方法, 刺激提示部位による危険判断 作業（後方）の正答率の比較

Fig. 10 Percentage correct in rear danger judgment task as a function of age, type of warning and attachment location of tactors.

意であった $(\boldsymbol{F}(2,36)=3.334, \boldsymbol{p}<0.05)$.

後方の危険場面に対する正答率に対して, 年齢, 刺激 提示法（7水準）の2要因について 2 元配置の分散分析を 行ったところ，年歯 $(\boldsymbol{F}(1,18)=4.846, \boldsymbol{p}<0.05)$ ，年歯 と刺激提示法の交互作用 $(\boldsymbol{F}(6,18)=2.538, \boldsymbol{p}<0.05)$ に 有意差が確認された。若年者，高齢者で，後方の危険場 面に対する正答率に関して，刺激提示方法間でFisherの PLSDによる多重比較を実施した結果，図10に示すよう な有意差が認められた。 
表4 年齢群ごとの危険判断作業（後方）の反応時間の結果に対する FisherのPLSDによる多重比較結果

Tab. 4 Results of multiple comparisons for reaction time to rear dangerous information by Fisher's PLSD for each age group.

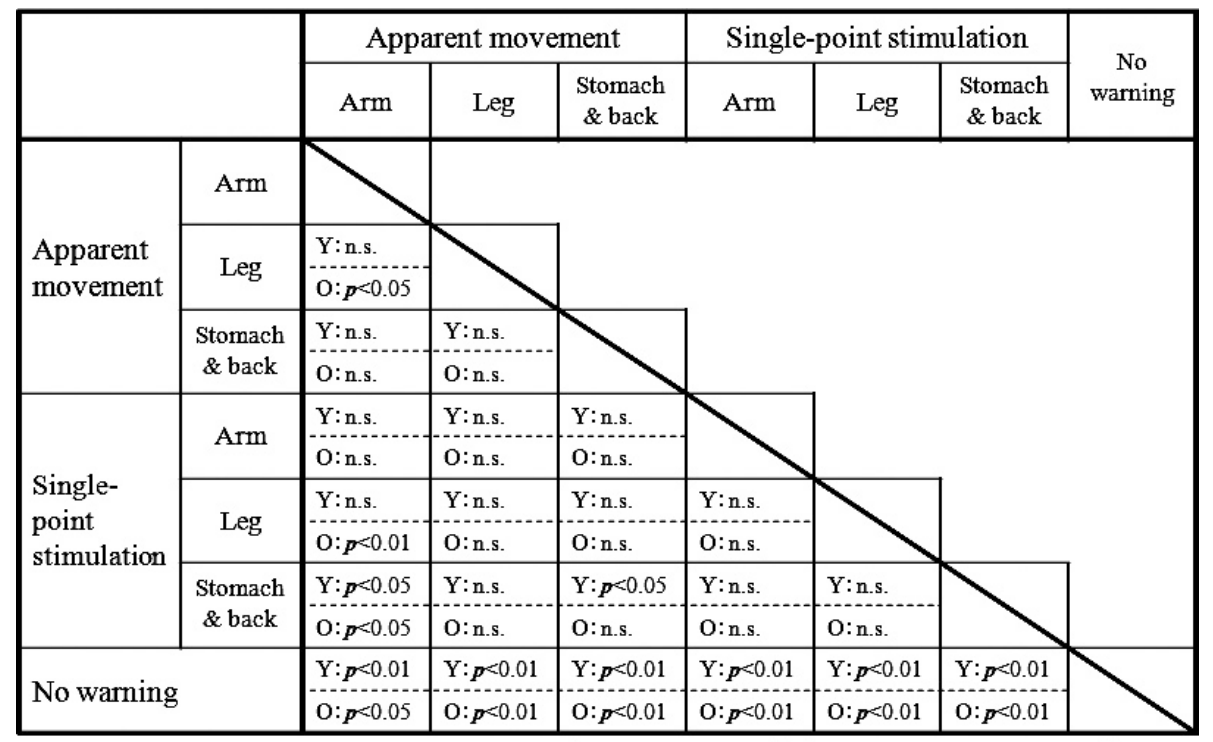

$\mathrm{Y}:$ Results on young adults. n.s. : not significant

$\mathrm{O}:$ Results on older adults.

\section{4. 考 察}

\section{4-1. 年齢の影響・警報提示の有効性}

高齢者は若年者に比べて平均して, スイッチ操作の正 答率が 0.985 倍, 前方の危険に対する正答率が 0.964 倍, 後方の危険に対する正答率 0.883 倍となった. これらの評 価指標よりも，トラッキング䛊差（図5), 前方の危険に 対する反応時間（図7），後方の危険に対する反応時間 （困8）において，高齢者と若年者の間で大きな差が認め られた。高齢者は若年者に比べて平均して, トラッキン グ誤差, 前方の危険に対する反応時間, 後方の危険に対 する反応時間がそれぞれ $3.434 ， 1.357 ， 1.281$ 倍となり， 高齢者の知覚・認知・運動機能の衰えがこれらの評価指 標に反映された。

図5（トラッキング䛊差）, 図6（スイッチ操作の正答 率), 困7 ・困9（前方の危険場面に対する反応時間と正 答率), 四8 - 図10（後方の危険場面に対する反応時間と 正答率）のいずれに関しても，高齢者は若年者よりも刺 激提示部位の影響を受けやすかったが, 若年者では刺激 提示部位の影響はほとんど受けなかった，すなわち，高 齢者と若年者の大きな違いとして, 高齢者は刺激提示部 位の影響を受けやすいことが明らかになった（高齢者の 特性に関しては，4-3で詳しく考察する).

また，図7（前方の危険場面に対する反応時間），困8
（後方の危険場面に対する反応時間），図9（前方の危険場 面に対する正答率）より，高齢者，若年者のいずれに関 しても，警報なしに比べて，警報あり（仮現運動もしく

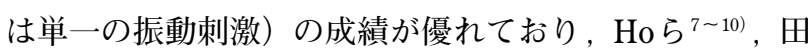
中ら ${ }^{11)}$, Murata $5^{12)}$ と同様に，触覚警報の有効性が確認 された。

\section{4-2. 刺激提示方法の影響}

高齢者, 若年者のデータを総合すると, 前方の危険場 面に対する反応時間に関しては, 刺激提示方法（仮現運 動と単一の振動刺激）で有意差は認められなかったが (図7参照)，後方の危険場面に対する反応時間に関して は, 単一の振動刺激のほうが仮現運動よりも反応時間が 有意に短くなり，仮現運動により方向性を有する触覚警 報が必ずしも速い反応につながるとは限らないことが明 らかになった. 前方と後方の危険場面に対する反応時間 に2つの振動刺激提示方法で差が生じたのは, 後方の危険 場面に対する判断では，前方に映し出されたトラッキン グ作業用の画面に注意しながら，バックミラーを介して 危険場面に対する判断を行うため，前方のトラッキング 画面に映し出される危険場面に対する処理よりも複雑な 認知的処理が必要であるためではないかと考えられる。 いずれの身体部位に関しても，振動子 2 個で, 前方から後 方，後方から前方への仮現運動を被験者が感知できたた め, 本研究では振動子の個数を 2 個より多くしなかった. 振動子の点数をさらに増やすことによって，仮現運動が 
より明確に知覚され，反応時間の短縮につながる可能性 もある. 今後の課題として, 複数点列で仮現運動を構成 した場合に危険場面に対する反応時間が短縮可能かどう かを明らかにしていく必要がある。

「1. はじめに」でも述べたとおり本研究では, 仮現運 動によって，危険場面の方向をより強く意識させ，単一 刺激よりも危険場面に対する速い反応が期待できる。す なわち，仮現運動により方向性を有した刺激提示を与え ることで, 自動車運転中の危険場面に対する警報提示法 としてのさらなる効果が認められると考えた。しかし， 本研究の範囲では, 大桑ら ${ }^{16)}$ によって提案された仮現運 動による警報提示の単一刺激に対する優位性は検証され なかった。すなわち, 仮現運動による触覚警報では後方 の危険場面に対する反応時間が長くなり，正答率が低下 することから，後方の危険場面に対する警報に関しては， 腕, 腹一背中による仮現運動の適用は望ましくない.

Murataら ${ }^{12)}$ では，左右方向の危険に対する触覚警報の 有効性を検討しているため, 方向性を付与しやすい（例 えば, 腕などの身体の左側, 右側への振動刺激によって それぞれ左側, 右側の危険への警報とすることが可能). 一方, 本研究のような前後方向に対する触覚警報では, 仮現運動による方法は単一の振動刺激よりも特に後方の 危険場面に対して反応時間が劣るという結果から判断す ると, 2 点の振動刺激による仮現運動を発生させて方向性 を付与しても，反応が速くなるとは限らず，前後方向の 危険に対する方向性を有する警報システムをさらに精緻 化していくためには，仮現運動以外の方法による方向性 提示のための技術開発が必要不可欠になる。

\section{4-3. 刺激提示部位の影響}

高齢者に関しては，図5より仮現運動による刺激を背 中／腹部に与えた場合にトラッキング誤差が最大となっ ている点, 図8より後方の危険場面に対して腕と背中／腹 部に仮現運動または単一の振動刺激による触覚警報を与 えた場合に反応時間が長くなった点, 図10より仮現運動 または単一の振動刺激による触覚警報を腕に提示を与え た場合に後方の危険場面に対する正答率が低下した点か ら, 仮現運動 (背中／腹部）, 仮現運動（腕）, 単一の振 動刺激 (腕), 単一の振動刺激（背中／腹部）の警報条件 は，高齢者に対しては不適切であると考えられる。一方， 高齢者では, 図8～10より両提示法（仮現運動，単一の 振動刺激）ともに刺激提示を脚に与えることにより，危 険に対して正確かつ速くに反応できることが確認された. 高齢者に関して, 後方の危険場面では脚に振動を与える ほうが背中／腹部，腕に振動を与える場合よりも反応時
間が短かった原因は，次のように推察される. Jonesら ${ }^{6}$ によって, 大腿部が腹部よりも振動に対する感度は高い ことが示されており, これも一つの要因として働いたの ではないかと考えられるが, 本研究の範囲ではこの原因 を明確に同定できない，高齢者に対する脚（大腿部）へ の仮現運動が後方の危険場面への反応時間を短縮する傾 向について，さらなるデータ収集によって検証していく 必要がある。

若年者に関しては, 高齢者とは対照的に, トラッキン グ誤差（図5），スイッチ操作の正答率（図6），前方・後 方の危険判断における反応時間（図7と図8), 正答率 (図9と図10)のいずれに関しても，触覚刺激提示方法に 関わらず，刺激提示部位で差がなかった。

特に, 後方の危険場面への反応時間に関する年齢と刺 激提示方法の有意な交互作用は，これらの点を裏付けて いる.

以上より, 年齢に応じて, 別々の触覚警報のデザイン 指針が必要であることが示唆される。ユニバーサルデザ インの観点から，高齢者に合わせて若年者の触覚警報を デザインする場合には，刺激提示部位は，脚が望ましい と考えられる。

今後の課題として, 本研究結果を実車実験によって検 証する必要がある．また，前後方向の危険に対して方向 性を有する警報を提示するために，仮現運動以外の有効 な方法（単一の振動刺激よりも速い反応が可能な方法） を提案する必要がある。さらに，振動子と身体部位の接 触面積の実験結果への影響等についても詳細に検討する 予定である。

\section{5. 結 論}

本研究では, 触覚インターフェースによる警報システ ムのデザイン指針を明らかにするために, 年齢, 触覚刺 激提示方法（仮現運動によって方法性を持たせた場合と 単一の振動刺激)，刺激提示部位を実験要因として，これ らがトラッキング（仮想運転）作業，スイッチ操作，前 後方向の危険場面に対する判断にいかなる影響を及ぼす かを明らかにした。攵の結果，若年者，高齢者に対して， それぞれ次の触覚警報のデザイン指針が望ましいことが 明らかになった。

(若年者)

- 両提示法（仮現運動, 単一の振動刺激）で刺激提示部 位による危険場面に対する反応時間と反応の正確さに は差がないため, 刺激提示部位として, 腕, 脚, 腹 部/背部のいずれも選択可能である。 


\section{（高齢者）}

- 両提示法（仮現運動，単一の振動刺激）で刺激提示を 脚に与えることにより, 危険に対して正確かつ速くに 反応できるため，刺激提示部位として脚が適切である. (两年齢群の共通事項)

・刺激提示方法としては, 仮現運動よりも単一の振動刺 激による触覚警報のほうが, 特に後方の危険場面に対 する反応時間を短縮できる。

\section{謝 辞}

本研究の一部は, 科学研究費基盤研究（B）（H22-H25 年度 : 安心感を高める自動車用コックピット・モジュー ル設計基盤技術）の援助のもとに行われた。

\section{参考文献}

1）大久保堯夫：人間工学から見た自動車運転者の視覚特 性の一考察, 自動車技術, 56 (3), 20-26, 2002.

2) 江部和俊, 大桑政幸, 稲垣大：ドライバの視聴覚認知に 伴う負担度評価, 豊田中央研究所R\&Dレビュー, 34 (3), $55-62,1999$.

3）津川定之：安全運転支援システムの現状と課題, 自動車 技術, 63 (2), 12-18, 2009 .

4）佐川浩一：自動車業界の取組み, 自動車技術, 59 (12), 15-20, 2005.

5） R. F. Schmidt：感覚生理学, 金芳堂, 80, 1980.

6) L. A. Jones and N. B. Sarter : Tactile displays: Guidance for their design and application, Human Factors, 50 (1), 90-111, 2008.

7) C. Ho, H. Z. Tan and C. Spence : Using spatial vibrotactile cues to direct visual attention in driving scenes, Transportation Research Part F, 8, 397-412, 2005.

8) C. Ho, H. Z. Tan and C. Spence: The differential effect of vibrotactile and auditory cues on visual spatial attention,
Ergonomics, 49 (7) , 724-738, 2006.

9) C. Ho, N. Reed and C. Spence: Assessing the effectiveness of "intuitive" vibrotactile warning signals in preventing front- to-rear-end collisions in a driving simulator, Accident Analysis and Prevention, 38, 988-996, 2006.

10) C. Ho and C. Spence : Using peripheral warning signals to orient a Driver's gaze, Human Factors, 51 (4), 539-556, 2009.

11）田中弘毅, 村田厚生：運転状況における触覚インターフ エースによる警報提示法の有効性に関する基礎研究, 第 43 回日本人間工学会中国・四国支部大会講演集, 32-33, 2009.

12) A. Murata, K. Tanaka and M. Moriwaka : Basic study on effectiveness of tactile interface for warning presentation in driving environment, International Journal of Knowledge Engineering \& Software Paradigm, 3 (1), 95-105, 2011.

13）山田喜一 ; 前方車両衝突警報の有効性についての考察, 自動車技術会論文集, 32 (1), 119-124, 2000.

14） R. Mohebbi, R. Gray and H. Z. Tan : Driver reaction time to tactile and auditory rear-end collision warnings while talking on a cell phone, Human Factors, 51 (1), 102-110, 2009.

15）大山正, 今井省吾, 和気典二 : 新編 感覚 - 知覚心理学八 ンドブック,誠信書房, 815, 1994.

16）大桑政幸, 中嶋敦史, 藤枝延維 : 自動車用シート振動刺 激による運転支援情報呈示法の開発, ヒューマンインタフ エース学会論文誌, 10 (3), 69-77, 2008.

17）村田厚生,王曙光：自動車用スイッチのタイプと設置位 置が操作性と視線の動きに及ぼす影響, 人間工学, 46 (6), 373-388, 2010.

18）家守進, 村田厚生, 早見武人, 田中弘毅：触覚インター フェースによる警報システム開発のための基礎的研究 一身体各部位に対する振動周波数と強度の同定一, 第 42 回日本人間工学会中国 ·四国支部大会講演論文集, 30-31, 2009. 